\title{
EFFECT OF MINIMUM QUANTITY LUBRICATION ON SURFACE ROUGHNESS AND TEMPERATURE IN MILLING OF EN31 STEEL FOR DIE MAKING
}

\author{
KEERTHANA Bhosetty ${ }^{1}$, VIJAYA KUMAR Gurram², ANAND BABU Kumba ${ }^{3}$ \\ ${ }^{1}$ SVU College of Engineering, Department of Mechanical Engineering, Tirupati,517502, Andhrapradesh, \\ India, e-mail: bubbly.keethu@gmail.com \\ ${ }^{2}$ SVU College of Engineering, Department of Mechanical Engineering, Tirupati,517502, Andhrapradesh, \\ India, e-mail: vijayluther2003@gmail.com \\ ${ }^{3}$ SVU College of Engineering, Department of Mechanical Engineering, Tirupati,517502, Andhrapradesh, \\ India, e-mail: kumba.anand@gmail.com
}

\begin{abstract}
Minimum Quantity Lubrication has enormous influence on the process parameters in machining. The main aim of the present work is to study the effects of spindle speed, depth of cut, tool material, amount of coolant dispensed and type of coolant on surface roughness and tool temperature in EN31 steel die making including Minimum Quantity Lubrication (MQL) by introducing a self-designed MQL setup and to optimize the responses using fuzzy-logic and Particle Swarm Optimization technique.
\end{abstract}

KEYWORDS: MQL, EN31 steel die making surface roughness and tool temperature, fuzzy-logic and Particle Swarm Optimization technique

\section{INTRODUCTION}

Although Non-traditional machining process are playing major role in machining industry, conventional milling process remains its importance as it is flexible in cutting keyways and slots etc.. In other hand Minimum Quantity Lubrication (MQL) refers a small amount (50$5600 \mathrm{ml} / \mathrm{hr}$ ) of lubricant dispensing system which is the substitute for the flood type lubricating system which dispenses $200 \mathrm{~L} / \mathrm{h}$ of lubricant and causes the soil as well the water contamination. "Minimum quantity lubrication (MQL) stands to be one of the most suitable techniques for cooling and lubricating the most conventional machining processes like milling, turning etc., In MQL a very small quantity of lubricant directed towards the cutting zone, [1] studied the effects of MQL on surface roughness the full sample set exhibited good surface finish conditions. The STD among the samples was $0.04 \mu \mathrm{m}$ and thus concluded that the MQL settings do not have a significant effect on the surface roughness. $900 \mathrm{ml} / \mathrm{hr}$ of lubrication dispensing is achieved with self-designed MQL setup for end milling, where lubricant and air is mixed by MQL set up which is based on spray gun concept [2]. The effects of MQL on tool wear, job dimension and surface finish in turning AISI-1040 Steel, MQL appeared to be effective in reducing surface roughness. However, it is evident that MQL improves surface finish depending upon the work-tool materials and mainly through controlling the deterioration of the auxiliary cutting edge by abrasion, chipping and built-up edge formation [3]. Taguchi's orthogonal array is well structured technique for Planning of experiments to study the entire parameter space with a reduced number of experiments $[4,5]$. When investigated the Surface Roughness in Drilling of Al 7075/10\% - SiCp Composite with uncoated and coated HSS tools under MQL Condition using Fuzzy Logic. Results exhibits that turning with MQL is a good alternative for conventional lubrication [6]. the traditional and non-traditional methods are studied for die making and [7] selected milling for machining of En-24, [8] investigated high speed milling process for die-cast manufacturing and increased quality, accuracy and speed of material processing, also reduced processing costs and saves 
machining time, [9] investigated and obtained a set of optimal machining parameters (i.e., spindle speed, depth of cut and feed rate) for face milling operations in order to minimize the surface roughness and to maximize the material removal rate using response surface methodology and are compared to the experimental results. En 31 steel has high resisting nature against wear and can be used for components which are subjected to severe abrasion, wear or high surface loading, good ductility and shock resisting, high degree of hardness with compressive strength and abrasion resistance, better tensile strength. En 31 steel has better mechanical, physical and thermal when compared to all engineering materials such as En 8, En 24, En 36 etc., [10] conducted experiments on machining of En 31 steel with different electrode materials (copper, brass and graphite) with electric discharge machining (EDM). [11] Focused on the analysis of optimum cutting conditions to get the lowest surface roughness and maximum material removal rate in $\mathrm{CNC}$ turning of different grades of $\mathrm{EN}$ materials. It shows that positive inserts are better than the negative inserts and EN-31 materials are superior to EN-8 for MRR. [12] carried out experimental work in electrical discharge machining (EDM) on EN31 (air hardened steel) using three different tool materials namely copper, aluminium and EN24, and also the problems involved in using graphite and brass as tool material are investigated. Various methods can be used to study the influences of process parameters on responses such as Response surface Methodology (RSM) Taguchi Based Desirability method, fuzzy based Particle Swarm Optimization (PSO) and Genetic Algorithm (GA) [13, 14, 15, 21]. The developed flexible classification algorithm by applying PSO to inventory classification is utilized as a single objective algorithm for cost minimization, demand correlation maximization, or inventory turnover ratio maximization [16]. Numerical studies were conducted by [17], and the classification performance of the PSO algorithm was comparable to other approaches. [18] Studied the significance of process parameters Pulse on time, pulse off time, peak current and servo voltage by applying ANOVA analysis for both MRR and SR. The optimal response values from RSM and PSO are compared. It is found that, the results of PSO are better than that of RSM, [19] compared genetic algorithms (GA) and simulated annealing (SA), and the proposed algorithm can improve the quality of the solution while speeding up the convergence process. Particle Swarm Optimization Technique is proved to be an efficient optimization algorithm when[20] conducted WEDM experiments on Monel 400 using Ezeecut NXG CNC WEDM and optimize the MRR and SR using PSO. When compared the relative performances of fuzzy based Particle Swarm Optimization (PSO) with Genetic Algorithm (GA), in the results the fuzzy based PSO system exhibits an improved holding ability than GA [21].

\section{DESIGN AND WORKING OF MQL SETUP}

As there are many setups are existing for maintaining minimum quantity lubrication which are of high cost and consume more space, for this work a setup is designed for maintaining minimum quantity lubrication which is more economical than other systems and is found to be best. The milling experiments are conducted on En-31 material for making die using solid carbide tool and HSS tools under MQL condition and the responses are optimized using particle swarm optimization and fuzzy logic methods and are compared. This prepared setup is tested many times for maintaining the lubricant as minimum as possible and for making the mist lubricant that it reaches the heat affected zone of the milling operations. In accordance to working procedure of the MQL setup, a cyclic timer connect to the compressor, which controls the power supply of compressor starts and stops according to the time that has been set in the cyclic timer i.e., 10sec. The air from compressor comes and lubricant from lubricant chamber comes simultaneously. At the end the air pressures the lubricant to impinge on to the work tool interface through the nozzle. The control valves control the air and coolant to the minimum required level. From this we obtained minimum of lubricant dispensed of $35 \mathrm{ml} / \mathrm{hr}$. 


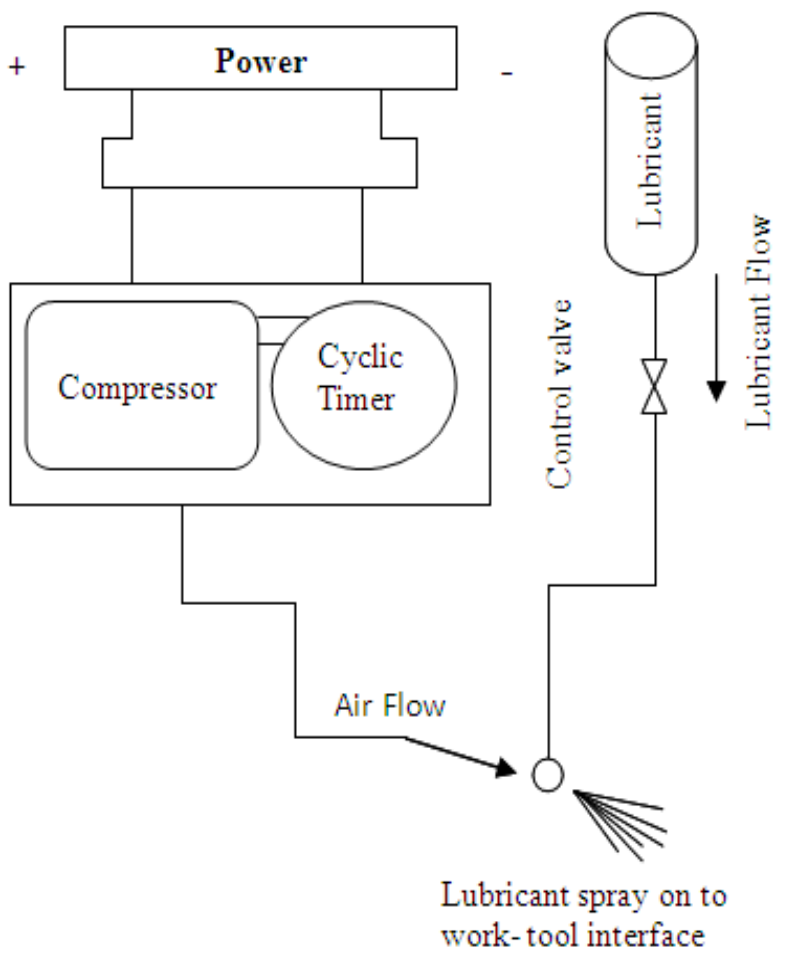

Fig. 1 MQL setup

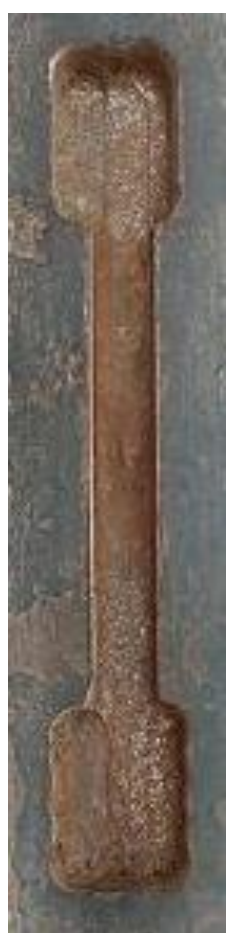

Fig. 2 I-section machined En 31 material

\section{EXPERIMENTAL WORK}

For this work, the milling operations were conducted on En 31 material, as per L18 orthogonal array which is designed using Minitab software by considering the parameters and their levels of Table 1 which influence the Milling process. Experiments were performed on $500 \times 80 \times 32 \mathrm{~mm}$ sized work piece in vertical milling machine. The work material is high hardened alloy steel with high resistance to wear, ductility and tensile strength. For machining of these hard material En 31, solid carbide and High-speed steel (HSS) are used during milling. Chemical composition of En 31 was given in Table2. The Experimental setup of milling process is shown in Fig.1. ASTM 370 Standards are considered for making I- Section and is made on the work material based on orthogonal array L18. The responses: Surface roughness and temperature are recorded in Table 3 by measuring with the help of talysurf and pyrometer for each experimental run.

Table 1: Process Parameters and their Levels

\begin{tabular}{cccc}
\hline \multirow{2}{*}{ Name of the Parameter } & \multicolumn{3}{c}{ Parameters Levels } \\
\cline { 2 - 4 } & level 1 & level 2 & level 3 \\
\hline Tool Material (TM) & HSS & SC \\
Speed (S in rpm) & 150 & 185 & 275 \\
Depth Of Cut (DOC in mm) & 0.25 & 0.5 & 0.75 \\
Coolant Type (CT) & $50 \% \mathrm{~W} \mathrm{in} \mathrm{SO}$ & $60 \% \mathrm{Win} \mathrm{SO}$ & $70 \% \mathrm{Win} \mathrm{SO}$ \\
Amount of Coolant Dispensed (ACD) & $50 \mathrm{ml} / \mathrm{hr}$ & $100 \mathrm{ml} / \mathrm{hr}$ & $150 \mathrm{ml} / \mathrm{hr}$ \\
\hline
\end{tabular}

*Note: W in SO -Water in Soluble Oil, HSS- High Speed Steel, SC- Solid Carbide 
Table 2: Chemical composition of En 31 alloy steel

\begin{tabular}{ccccccc}
\hline Steel & \multicolumn{5}{c}{ Chemical Composition in \% } \\
\cline { 2 - 7 } Material & $\mathrm{C}$ & $\mathrm{Mn}$ & $\mathrm{Si}$ & $\mathrm{S}$ & $\mathrm{P}$ & $\mathrm{Cr}$ \\
\hline EN 31 & 0.9 & 0.3 & 0.10 & 0.4 & 0.4 & 1.0 \\
\hline
\end{tabular}

Table 3: Experimental design and measured Response values

\begin{tabular}{|c|c|c|c|c|c|c|c|c|c|c|c|c|c|c|}
\hline \multirow{2}{*}{\multicolumn{6}{|c|}{ Experimental design }} & \multicolumn{8}{|c|}{ responses } & \multirow{3}{*}{$\begin{array}{l}\text { Fuzzy } \\
\text { Grade }\end{array}$} \\
\hline & & & & & & \multicolumn{4}{|c|}{$\begin{array}{l}\text { Surface Roughness } \\
(\mu \mathrm{m})\end{array}$} & \multicolumn{4}{|c|}{$\begin{array}{l}\text { Tool Temp } \\
\left({ }^{0} \mathrm{C}\right) \\
\end{array}$} & \\
\hline $\begin{array}{l}\text { Ex } \\
\text { No }\end{array}$ & $\mathrm{TM}$ & $\begin{array}{c}\mathrm{S} \\
(\mathrm{rpm})\end{array}$ & $\begin{array}{l}\text { DOC } \\
(\mathrm{mm})\end{array}$ & $\begin{array}{c}\text { CT } \\
\text { (W } \\
\text { in } \\
\text { SO) }\end{array}$ & $\begin{array}{c}\mathrm{AC} \\
\mathrm{D} \\
\mathrm{ml} / \mathrm{h} \\
\mathrm{r}\end{array}$ & $\begin{array}{c}\text { Trial } \\
1\end{array}$ & $\begin{array}{c}\text { Trial } \\
2\end{array}$ & $\begin{array}{c}\text { Trial } \\
3\end{array}$ & Avg. & $\begin{array}{c}\text { Trial } \\
1\end{array}$ & $\begin{array}{c}\text { Trial } \\
2\end{array}$ & $\begin{array}{c}\text { Trial } \\
3\end{array}$ & Avg. & \\
\hline 1 & HSS & 150 & 0.25 & $50 \%$ & 50 & 0.75 & 0.88 & 0.83 & 0.82 & 31.5 & 32.1 & 31.5 & 31.7 & 0.6344 \\
\hline 2 & HSS & 150 & 0.5 & $60 \%$ & 100 & 1.15 & 1.25 & 1.2 & 1.2 & 32.7 & 33.5 & 32.8 & 33 & 0.2805 \\
\hline 3 & HSS & 150 & 0.75 & $70 \%$ & 150 & 1.08 & 1.12 & 1.22 & 1.14 & 34.3 & 33.7 & 34.6 & 34.2 & 0.2514 \\
\hline 4 & HSS & 185 & 0.25 & $50 \%$ & 100 & 0.54 & 0.58 & 0.56 & 0.56 & 32.8 & 33.5 & 34.2 & 33.5 & 0.5224 \\
\hline 5 & HSS & 185 & 0.5 & $60 \%$ & 150 & 0.78 & 0.76 & 0.86 & 0.8 & 31.4 & 31.8 & 31.3 & 31.5 & 0.696 \\
\hline 6 & HSS & 185 & 0.75 & $70 \%$ & 50 & 0.24 & 0.26 & 0.25 & 0.25 & 32.8 & 34.2 & 33.5 & 33.5 & 0.6677 \\
\hline 7 & HSS & 275 & 0.25 & $60 \%$ & 50 & 0.62 & 0.68 & 0.74 & 0.68 & 32.9 & 34.6 & 33.9 & 33.8 & 0.4208 \\
\hline 8 & HSS & 275 & 0.5 & $70 \%$ & 100 & 0.25 & 0.28 & 0.31 & 0.28 & 32.2 & 32.2 & 32.2 & 32.2 & 0.7464 \\
\hline 9 & HSS & 275 & 0.75 & $50 \%$ & 150 & 0.42 & 0.47 & 0.49 & 0.46 & 31.5 & 32.3 & 31.3 & 31.7 & 0.7371 \\
\hline 10 & $\mathrm{SC}$ & 150 & 0.25 & $70 \%$ & 150 & 0.34 & 0.39 & 0.41 & 0.38 & 32.8 & 33.6 & 33.2 & 33.2 & 0.6511 \\
\hline 11 & $\mathrm{SC}$ & 150 & 0.5 & $50 \%$ & 50 & 0.31 & 0.35 & 0.3 & 0.32 & 32.1 & 32.2 & 32.1 & 32.2 & 0.7221 \\
\hline 12 & $\mathrm{SC}$ & 150 & 0.75 & $60 \%$ & 100 & 0.38 & 0.42 & 0.46 & 0.42 & 33.2 & 33.4 & 33.6 & 33.4 & 0.5917 \\
\hline 13 & SC & 185 & 0.25 & $60 \%$ & 150 & 0.68 & 0.72 & 0.7 & 0.7 & 32.8 & 32.5 & 33.4 & 32.9 & 0.5482 \\
\hline 14 & $\mathrm{SC}$ & 185 & 0.5 & $70 \%$ & 50 & 0.21 & 0.23 & 0.25 & 0.23 & 32.5 & 32.7 & 32.9 & 32.7 & 0.7602 \\
\hline 15 & $\mathrm{SC}$ & 185 & 0.75 & $50 \%$ & 100 & 0.27 & 0.33 & 0.3 & 0.3 & 31.8 & 32.3 & 32.8 & 32.3 & 0.7291 \\
\hline 16 & $\mathrm{SC}$ & 275 & 0.25 & $70 \%$ & 100 & 0.2 & 0.26 & 0.23 & 0.23 & 33.8 & 34.1 & 34.4 & 34.1 & 0.6098 \\
\hline 17 & $\mathrm{SC}$ & 275 & 0.5 & $50 \%$ & 150 & 0.3 & 0.35 & 0.31 & 0.32 & 32.7 & 34.2 & 33.6 & 33.5 & 0.6128 \\
\hline 18 & $\mathrm{SC}$ & 275 & 0.75 & $60 \%$ & 50 & 0.38 & 0.4 & 0.42 & 0.4 & 34.5 & 34.7 & 35.2 & 34.8 & 0.4052 \\
\hline
\end{tabular}

Table 4. The fuzzy grade for each parameter at each level

\begin{tabular}{llllll}
\hline Level & TM & S & DOC & CT & ACD \\
\hline 1 & 0.550744 & 0.5217 & 0.56445 & 0.659483 & 0.601567 \\
2 & 0.625467 & 0.653933 & 0.636167 & 0.4904 & 0.579983 \\
3 & 0.588683 & 0.5637 & 0.614433 & 0.582767 & \\
Delta & 0.074722 & 0.132233 & 0.072467 & 0.169083 & 0.021583 \\
Rank & 3 & 2 & 4 & 1 & 5 \\
\hline
\end{tabular}

\section{OPTIMIZATION OF THE RESPONSES}

The experimental responses were optimized using the fuzzy logic technique and particle swarm optimization technique

\subsection{Fuzzy logic technique}

Responses are optimized using fuzzy-logic technique and fuzzy-logic is performed using matlab software. The fuzzy grade is tabulated in the table 3 and it is calculated for each parameter 
at each level as tabulated in table4 and shown in fig.3. From the optimization based on Fuzzy, with reference to thefigure 3 , the optimal conditions can be noted as

Tool material at level 2 i.e. SC tool,

Speed at level 2 i.e. $185 \mathrm{rpm}$,

Depth Of Cut at level 2, i.e. $0.5 \mathrm{~mm}$,

Coolant Type at level 3, i.e. $70 \%$ water in soluble oil and

Amount of Coolant Dispensed at level 1, i.e. $50 \mathrm{ml} / \mathrm{hr}$.

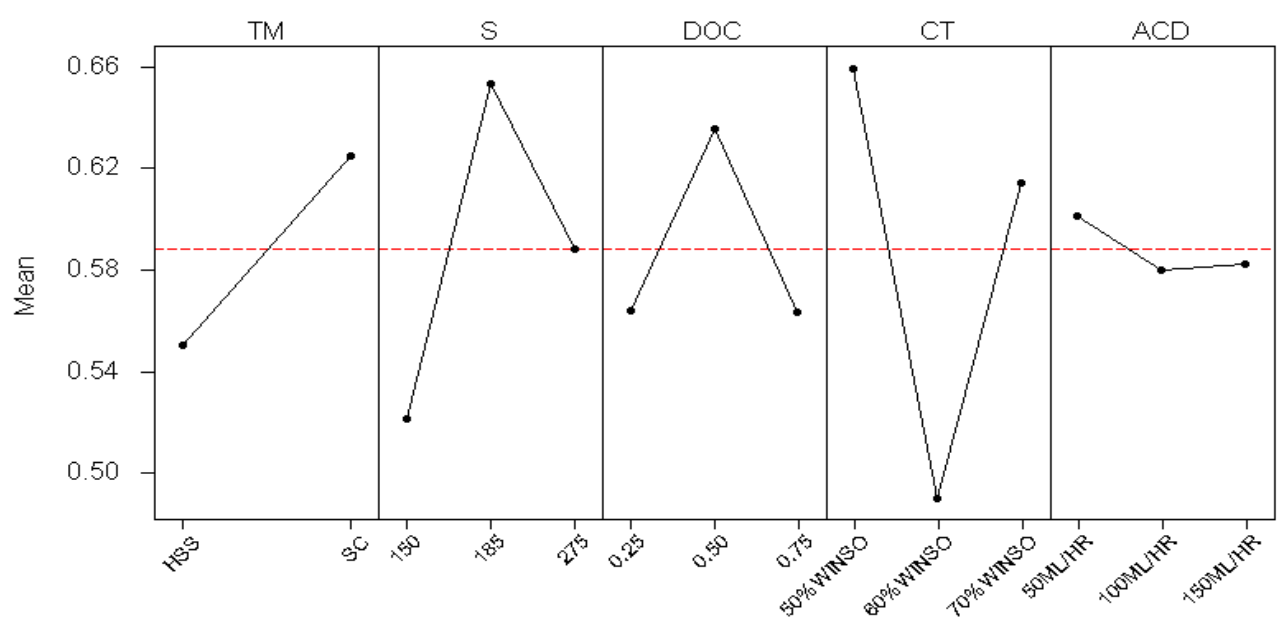

Fig.3. The fuzzy grade for each parameter at each level

*Note: TM: Tool Material, S: Speed, DOC: Depth of Cut, CT: Coolant Type, ACD: Amount of Coolant Dispensed, HSS: High Speed Steel, SC: Solid Carbide W in SO: Water in Soluble Oil.

\subsection{Particle swarm optimization}

As a foremost step, the mathematical relationship between process parameters and machining outputs is obtained through the method of multiple regressions with the assistance of MINITAB 13.1(Software Package for Statistical Solutions). Quadratic models were developed by using regression analysis to determine the relation of process parameters with Temp, MRR and SR. These models were developed at $95 \%$ confidence level.

Regression model of Surface Roughness

$\mathrm{SR}=1.26-0.321 \mathrm{TM}-0.159 \mathrm{~S}-\mathbf{0 . 0 3 3 3} \mathrm{DOC}-\mathbf{0 . 0 2 2 5} \mathrm{CT}+0.0917 \mathrm{ACD}$

Correlation coefficient is $55.3 \%$.

Regression model of Temperature

$\mathrm{TEMP}=31.3+0.440 \mathrm{TM}+0.203 \mathrm{~S}+0.058 \mathrm{DOC}+0.420 \mathrm{CT}-0.142 \mathrm{ACD}$

Correlation coefficient is $100 \%$.

Regression models are used for obtaining the optimization results with PSO algorithm. A single objective optimization normally gives one optimal solution. In practical situations, most of the problems are multi objective; there could be a number of optimal solutions minimizing the objective value that is necessary to determine the optimal process parameters. 
We have used an open source MATLAB PSO toolbox. The code was verified and then used for our project. In the code, $\mathrm{c}_{1}=1.2, \mathrm{c}_{2}=0.012$ and $\mathrm{w}=0.0004$. Maximum number of iterations is taken as 2000 and the population size is 50 .

The fitness function used for multi-objective optimization was given by

\section{$\operatorname{Min}(\mathrm{Z})=\mathbf{w} 1 * \mathrm{SR}+\mathrm{TEMP} * \mathbf{w} 2$}

Where $\mathrm{w} 1$ and $\mathrm{w} 2$ are equal weights assigned to each equation.

\section{$\operatorname{Min}(Z)=16.28+0.0595 T M+0.022 S+0.01235$ DOC+0.1987CT-0.02515ACD}

Fig 4 shows the convergence of PSO to obtain an optimized trend and the best objective value achieved during each iteration. It describes the efficiency of the algorithms to initially explore through the solution space and converge to a near optimal or best optimal solution towards the termination of the algorithm. The algorithm was executed for several times to make sure the repeatability of the results. Table shows the optimized and experimental results. The error between the experimental and predicted results was reasonably small, i.e. less than $10 \%$. Results showed that this approach can be effectively used to find the near optimum performance of alloy.

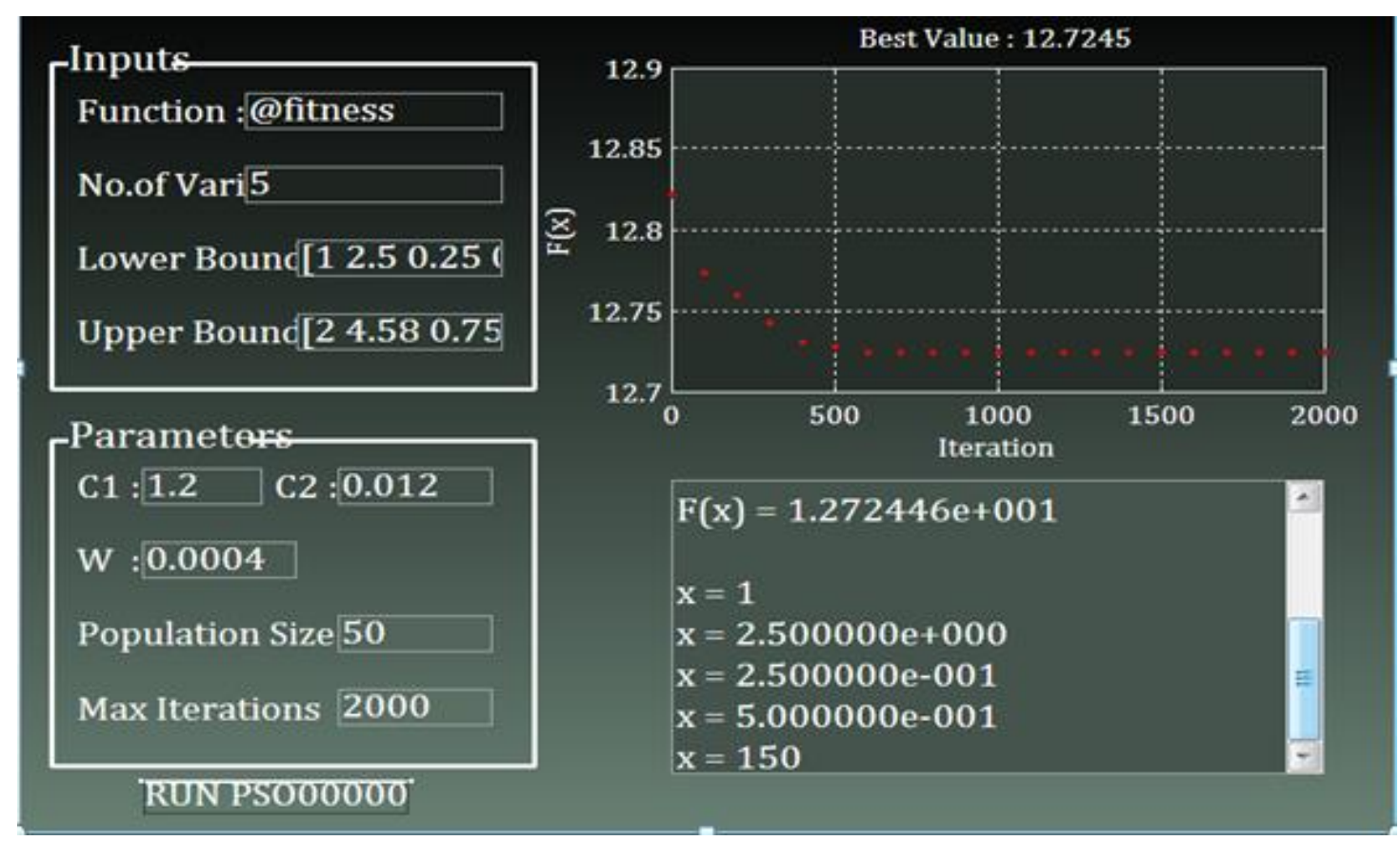

Fig 4. PSO Tool Box

From the optimization based on PSO, with reference to the above PSO tool box, the optimal conditions can be easily noted down as

- Tool material at level 1 i.e., HSS tool,

- Speed at level 1 ie,.150rpm,

- Depth Of Cut at level 1, ie,.0.25mm,

- Coolant Type at level 1, ie,.50\% water in soluble oil and

- Amount of Coolant Dispensed at level3, i.e., .150ml/hr.

\section{Confirmation experiment}

The confirmation tests have been conducted for the obtained optimal combination of process parameters from fuzzy and PSO techniques and results are tabulated in the table 5. 
Table 5. The confirmation experimental results

\begin{tabular}{cccc}
\hline \multirow{2}{*}{ Method } & Optimal combination & \multicolumn{2}{c}{ Confirmation experimental results } \\
& Surface roughness & Tool temperature \\
\hline Fuzzy Logic & TM2S2DOC2CT3ACD1 & 0.21 & 31.0 \\
PSO & TM1S1DOC1CT1ACD3 & 0.15 & 29.0 \\
\hline
\end{tabular}

\section{Conclusions}

- From the experimental results, it is revealed that the surface roughness and tool temperature are well optimized using PSO technique.

- From table 4 it is concluded that coolant type most influential parameter in milling for considered responses.

- Tool material has medium effect on responses.

- Depth of cut and Amount of coolant dispensed are least influence the responses.

- Since from confirmation test results, it is concluded that PSO is the best method from optimal combination obtained.

\section{References}

[1] Tunc, L. T., Gu, Y., Burke, M. G. "Effects Of Minimal Quantity Lubrication (MQL) On Surface Integrity In Robotic Milling Of Austenitic Stainless Steel”, Procedia CIRP 45, pp. 215 - 218, 2016. DOI: 10.1016/j.procir.2016.02.337

[2] Kedare S. B, Borse D.R, and Shahane P. T. "Effect of Minimum Quantity Lubrication (MQL) on Surface Roughness of Mild Steel of 15HRC on Universal Milling Machine" Procedia Materials Science 6, pp. 150 - 153, 2014. DOI: 10.1016/j.mspro.2014.07.018

[3] Dhar, N. R., Islam, M. W. "A Study of Effects of MQL on Tool Wear, Job Dimension and Finish in Turning AISI-1040 Steel", AEESEAP Journal of Engineering Education 31 (2), pp. $15-22,2017$.

[4] Himanshu, P. R., Lalta, P., Mayank, P., Vineet, Ti. “An Estimating The Effect Of Process Parameters On Metal Removal Rate And Surface Roughness In Wedm Of Composite Al6063/Sic/A12o3 By Taguchi Method“, Journal of Mechanical Engineering - Strojnícky časopis 67 (2), pp. 25 - 36, 2017. DOI: 10.1515/scjme-2017-0015

[5] Beri, N., Maheshwari, S., Sharma, C., Kumar, A. "Machining Performance Evaluation During Electric Discharge Machining Of Inconel 718 Using The Taguchi Methodology“، Journal of Mechanical Engineering - Strojnícky časopis 62, (5-6), pp. 299 - 310, 2011.

[6] Anand Babu, K., Vijaya Kumar, G., Venkataramaiah, P. "Prediction of Surface Roughness in Drilling of Al 7075/10\% - SiCp Composite under MQL Condition using Fuzzy Logic", Indian Journal of Science and Technology 8 (12), pp. 1 - 10, 2015. DOI: 10.17485/ijst/2015/v8i12/54074

[7] Shahriar, J. H., Md, Nafis, A. "A neuro-fuzzy approach to select cutting parameters for commercial die manufacturing", Procedia Engineering 90, 753 - 759, 2014. DOI: https://doi.org/10.1016/j.proeng.2014.11.809

[8] Andris, L., Toms, T. "The Influence of High-Speed Milling Strategies on 3D Surface Roughness Parameters", Procedia Engineering 100, pp. 1253 - 1261, 2015. DOI: 10.1016/j.proeng.2015.01.491 
[9] Jurkovic, J., Korosec, M., Kopac, J. "New approach in tool wear measuring technique using CCD vision system“, International Journal of Machine Tools and Manufacture 45 (9), pp. 1023 - 1030, 2005.

[10] Rajesh, Ch., Kumar, H., Garg, R. K. "Analysis and Evaluation of Heat Affected Zones in Electric Discharge Machining of EN 31 Die Steel", Indian Journal of Engineering \& Material Sciences 17, $91-98,2010$.

[11] Dave, H. K., Patel, L. S, Raval, H. K. "Effect of machining conditions on MRR and surface roughness during CNC Turning of different Materials Using TiN Coated Cutting Tools - A Taguchi approach", International Journal of Industrial Engineering Computations 3, pp. 925 - 930. 2012.

[12] Arunkumar, N., Shareef Abdur Rawoof, H., Vivek, R. "Investigation on the Effect Of Process Parameters For Machining Of EN31 (Air Hardened Steel) By EDM", International Journal of Engineering Research and Applications 2 (4), pp. 1111 - 1121, 2012.

[13] Srinivasa Rao, M., Ramanaiah, N. "Optimization Of Process Parameters For Fsw Of AlMg-Mn-Sc-Zr Alloy Using Ccd And RSM“, Journal of Mechanical Engineering Strojnícky časopis 68 (3), pp. 195 - 224, 2018. DOI: 10.2478/scjme-2018-0035

[14] Gopalakannan, S., Senthilvelan, T., Kalaichelvan, K. "Modelling And Optimization Of Edm Process Parameters On Machining Of Al 7075/Sic Metal Matrix Composite By Applying Response Surface Method“, Journal of Mechanical Engineering - Strojnícky časopis 63 (1), pp. 37 - 54, 2012.

[15] Ramanujam, R., Raju, R. "Process Parameter Optimization In Turning Of Al$\mathrm{Sic}_{\mathrm{p}}$ Composites Using Taguchi Based Desirability Function Analysis“, Journal of Mechanical Engineering - Strojnícky časopis 62 (2), 81 - 92, 2011.

[16] Rajeswari, K., Lakshmi, P. "A Pso-Tuning of Fuzzy Logic Controller For Vehicle Suspension System“, Journal of Mechanical Engineering - Strojnícky Časopis 61 (4), pp. $215-232,2010$.

[17] Tsai, C. Y., Yeh, S. W. "A multiple objective particle swarm optimization approach for inventory classification", International Journal of Production Economics 114 (2), pp. 656 - 666, 2008.

[18] Sreenivasa Rao, M., Venkaiah, N. "Parametric Optimization In Machining Of Nimonic263 Alloy Using RSM And Particle Swarm Optimization", Procedia Materials Science 10, pp.70 - 79, 2015. DOI: https://doi.org/10.1016/j.mspro.2015.06.027

[19] Cus, F., Zuperl, U., Gecevska, V. "High speed end-milling optimization using Particle Swarm Intelligence", Journal of Achievements in Materials and Manufacturing Engineering 22 (2), pp. 75 - 78, 2007.

[20] Rajyalakshmi, G., Koushik, T., Kalyan, T. "Parametric Optimization In Wedm Using Particle Swarm Optimization Technique", 56th IRF International Conference, Pune, India, 2016. ISBN: 978-93-86083-26-5.

[21] Kennedy, J., Eberhart, R. "Particle Swarm Optimisation", Proceedings of ICNN'95 International Conference on Neural Networks, pp. $1942-1948,1995$. DOI:10.1109/ICNN.1995.488968 